\title{
A Linguistic Integrative Model for Enhancing College Students' English Reading Competence
}

\author{
Magda Madkour ${ }^{1}$ \\ ${ }^{1}$ College of Languages and Translation, Al-Imam Mohamed Ibn Saud Islamic University, Riyadh, Saudi Arabia \\ Correspondence: Dr. Magda Madkour, College of Languages and Translation, Al-Imam Mohamed Ibn Saud \\ Islamic University, Riyadh, Saudi Arabia. E-mail: magdasilver@yahoo.com
}

Received: May 22, 2016

Accepted: June 14, 2016 Online Published: July 13, 2016

doi:10.5539/ijel.v6n4p60

URL: http://dx.doi.org/10.5539/ijel.v6n4p60

\begin{abstract}
This quantitative correlational research focused on investigating the relationship between linguistic technology-based integrative teaching approaches and college students' reading competence. The study occurred in five phases. The first phase involved observing four reading classes to collect data on teaching methodologies. The second phase was based on identifying the problems that affect students' English reading performance. The researcher selected a random sample of 100 female freshmen students from the College of Languages and Translation at Al-Imam Mohamed Ibn Saud Islamic University (IMAMU Univ.), Riyadh, Saudi Arabia. The participants responded to a Likert questionnaire regarding their reading problems and strategies. In the third phase, the participants took a reading comprehension exam to determine their exact reading levels. The preliminary data showed the presence of a high degree at the scale of difficulties that students faced in reading comprehension. Students had problems in loud and silent reading, reading speed, and critical and inferential reading, which reflected students' weak reading skills. The study also pointed to the ineffective traditional teaching strategies as the main cause of this problem. Traditional teaching strategies which depend on general lectures and explaining the mechanical structure of the reading passages did not help students use their cognitive abilities to improve their reading comprehension. The fourth phase of the present study required selecting an experimental group of 35 students from the same sample to be taught using the linguistic integrative model for five weeks. At the end of the fifth week, a reading comprehension exam was given to the group to determine the impact of the new teaching methodology on students' reading competence. The comprehension test was adopted from ACCUPLACER, an integrated computer-assessment designed to evaluate students' reading skills. The test is designed by Board College in USA, which is a specialized agency in college students' exams, and it offers diagnostics and intervention support to help students prepare for academic course work. The reading exam covers six skills, including: understanding the text's purpose and tone; identifying the central ideas; recognizing supporting details; understanding sentences and vocabulary relationships; distinguishing illustration, comparison and contrast, and cause and effect relationships; and understanding inferential meanings. The data analysis showed a significant difference in favor of students who used the linguistic integrative model, indicating the positive impact of technology-based teaching approaches on students' proficiency in reading. Based on the results of this study, the researcher made the following recommendations: integrate educational technology into teaching the reading courses at the college; provide professional programs for teachers to train them to use the linguistic integrative approaches; and provide linguistic laboratories that are equipped with modern technologies, including reading software, to intensify students' reading practices. The significance of this study is that it is a contribution in the field of teaching English as a foreign language in general, and reading in particular since it provides a new model that integrates the technology of hypertexts, e-learning, and data mining analysis into a number of linguistic theories including schema theory, the information processing theory, and Krashen's (1981; 1995) language theory. Providing teachers with training pertinent to the integration of technology into teaching is an important step towards implementing cognitive and metacognitive teaching methods, which will reinforce the efforts of the College of Languages and Translation towards achieving international accreditation.
\end{abstract}

Keywords: cognitive teaching approaches, educational technology, EFL reading skills, integrative teaching methodology, linguistic theories 


\section{Introduction}

Reading is a complex mental ability that requires cognitive and metacognitive development, and it is one of the most important components of language learning. Students' reading competence is reflected in their ability to read loudly and silently, and communicate what they understand from the reading texts fluently. Students' reading competence is also a significant indicator of language proficiency. However, research (Ahmadi, Ismail, \& Abdullah, 2013; Ari, 2015; Bell, 2004; Dickens \& Meisinger, 2016; Douglas et al., 2016; Gorzycki et al., 2016; Jiang, 2015; Kwon \& Linderholm, 2015; Mishra, 2014; Schuster, 2012; Shih , 2015; Springer, Wilson, \& Dole, 2015; Wilson-Fowler \& Apel, 2015) indicated that college students had difficulties in reading comprehension, reading interpretation, reading speed, critical and inferential reading, and word recognition, all of which affected reading competence. These research studies also showed that students with inadequate reading skills had problems not only in achieving their academic objectives, but also in performing cognitive tasks in real life. Therefore, the current study aimed at identifying the difficulties affecting students' reading competence, and providing some appropriate solutions.

\subsection{Problem Statement}

The current research was based on examining the impact of applying a linguistic integrative teaching approach on enhancing college students' English reading competence. Students complained that the traditional teaching methodologies employed in their reading courses at the College of Languages and Translation, at IMAMU University did not help them to achieve reading proficiency. Students emphasized that using traditional strategies that relied on general lectures and direct instruction did not motivate them to improve their reading skills. Evidence from students' midterm and final exam records indicated that students' low scores in reading hindered them from improving their overall performance in English. Data from class observation revealed that the teaching methods affected students' performance in reading. Students were unable to complete their academic tasks, which impeded their college success, consequently their future careers. Additional evidence from previous research (Boatman \& Long, 2010; Dickens \& Meisinger, 2016; Gruenbaum, 2012; Hendricks, 2013; Linderholm et al., 2014; Madkour, 2011; Springer et al., 2015; Tang, 2016) showed that ineffective instruction impacted students' reading ability and skills negatively. Hence, the present research focused on identifying the difficulties that freshmen students encountered in reading literary and scientific textbooks, and supplementary materials.

\subsection{Purpose Statement}

The purpose of this quantitative correlational study was to investigate the impact of implementing a linguistic integrative model on students' reading competence. Integrating linguistic theories of reading into modern technology can provide teachers with numerous resources to help students enhance their reading capabilities. Research (Eskenazi, Michael, \& Folk, 2015; Linderholm et al., 2013; O'Sullivan \& Dallas, 2010; Reid, 2013; Tang, 2016; Yang, 2010) indicated that reading instruction had influenced students' ability to read fluently and efficiently. Research (Dreyer \& Nel, 2003; Grgurović, Chapelle, \& Shelley, 2013; Shang, 2015; Tsai et al., 2016; Wright, Fugett, \& Francine, 2013) also showed that integrating modern technology into teaching strategies resulted in improving students' performance in reading comprehension and reading strategies. To investigate such integration, the present study collected data from 100 undergraduate students at the College of Languages and Translation, IMAMU University. Data collection depended on using a Likert scale questionnaire to identify students' problems. Then, a group of 35 students was selected randomly from the same sample, and was taught implementing the integrative model. The comprehension test was adopted from ACCUPLACER, an integrated computer-assessment designed to evaluate students' reading skills. Data was analyzed using the Statistical Package for the Social Sciences (SPSS).

\subsection{Definitions}

Cognitive Teaching Approaches: refer to teaching methodologies that are based on cognition, i.e., using mental abilities to perceive, process, analyze, and evaluate knowledge (The University of Kansas, 2015).

Data Mining: is the process of analyzing data from various perspectives as a means of discovering knowledge. Data mining can be conducted using data mining software which allows users to analyze, categorize, and summarize relationships in the text to find correlations or patterns. Data mining techniques include data management, data pre-processing, inference, and visualization (Han, Kamber, \& Pei, 2012).

E-Reading: refers to reading books, articles, and newspapers using the Internet, or on portable devices such as e-book readers, kindle tablets, iPad, computers, or smart phones. Using e-books helps to enrich extensive reading to motivate students to read regularly. The effect of e-reading on EFL and ESL students is enormous as it motivates them to become interested in reading to improve their reading skills (Chen et al., 2013). 
Hypertext: refers to the text displayed using a computer or electronic devices. Including references as hyperlinks in the text, readers can immediately access any information to develop their understanding of the text. Instead of using a text linear format, information in hypertexts is presented in a semantic network when all the sections of the texts are connected to each other. The prefix hyper means over or beyond, and hence the implication that readers can use hypertexts as a strategy to navigate through the different nodes of the text to penetrate into deeper meanings (Salmeron et al., 2004).

Inferential Reading: involves using inference skills while reading a text, such as identifying the author's tone, purpose, and point of view, recognizing implied ideas, identifying causal relations, comparing and contrasting ideas, and drawing logical conclusions from the text to make the meaning explicit (Brandom, 1998).

Integrative Teaching Approaches: are teaching methodologies that are based on integrating technology into instruction. Modern technologies such as e-reading devices, digital processing computers, and information technology are some means that teachers can use in adding new dimensions to the learning-teaching process and resources to motivate and support students (Gredler, 2009).

Metacomprehension: refers formally to the process of understanding online reading materials; however, the term is used now to refer to understanding the text at deep levels, and to reader's ability to monitor the degree of understanding and interpreting the information of various types of texts (Resnick, 2010).

Text Processing: refers to the process of manipulating electronic texts, i.e., the analysis, and retrieval of information using computers, and it involves using the linguistic approach of language analysis and understanding, including syntactical and semantic analyses (Salton, 1989).

\subsection{Significance of the Study}

This research targeted four areas which constitute effective reading: new trends for teaching college students reading; cognitive-based reading strategies; integrating technology into teaching and learning reading skills; and putting linguistic reading theories into practice. The study examined the impact of adopting a linguistic technology-based integrative model for enhancing English students' reading competences. The present study highlighted the procedures that were applied in technology-based teaching at higher education, encompassing e-learning, hypertext reading, and data mining analysis. Furthermore, this study can stimulate a greater interest in implementing computer-based assessment, especially for higher education. Thus, the study is a contribution in teaching reading skills employing technology to enhance inferential reading, meta-comprehension, and reading interpretation. A further significance of this study is that it has integrated such learning theories as the schema theory, the information processing theory, and Krashen's $(1981 ; 1995)$ language theory. This research also provides some recommendations for the College of Languages and Translation, at IMAMU University to foster the process of attaining the international accreditation.

\subsection{Theoretical Framework}

The conceptual base of the current study depends on integrating a number of theories which include schema theory, information processing theory and some linguistic theories of reading. The integration of these theories helps in understanding how to use technology in teaching reading skills. The first theory is the schema theory, which was proposed by Kant (1781), and was developed by Gestalt psycholinguist Bartlett (1985). Rumelhart (1980) and Anderson (1999) applied the schema theory in education to help students interpret what they understand, combining prior knowledge to process the information of the texts. Carrell (1984) identified three types of schema: linguistic schema, content schema, and formal schema. While Linguistic schema refers to the reader's prior linguistic knowledge, including phonetics, grammar, and vocabulary, content schema means the reader's background knowledge about the topic which includes culture. Formal schema involves the meta-linguistic coherent patterns, and textual organization which help the readers to increase expectations while reading the text. According to Rumelhart $(1980 ; 1985)$, students use their cognitive abilities to understand how prior information and the structure of the texts are accumulated together in units to constitute the schema. When students understand and analyze these units, they can increase their reading comprehension and reading speed, and can also provide critiques on what they read. The schema theory can be used to understand various levels of the text. For example, Samuels (1994) developed LaBerge-Samuels Model of Automatic Information Processing (AIP) to explain how the internal aspects of attention are crucial to comprehension. The internal aspects of attention embrace readers' alertness, i.e., active attempt to understand letter-sound relationships, syntactic structure, and word meaning. Stanovich's (1980) Interactive-Compensatory Model explains how reading can be developed using the semantic relationships of the text. Rumelhart's (1994) Interactive Model demonstrates the way information is received from several sources of knowledge, including letter-sound relationships, syntactic relationships, and sequence of events, which are processed simultaneously. According to this model, readers can 
use any source such as contextual clues or prior knowledge to understand the text. Ruddell, Ruddell, and Singer (1994) used the schema theory for constructing meaning, based on processing sociocognitive information. Using this model in the classroom, comprehension is perceived as a process that requires negotiation of meaning among the text, students, and teachers. Moreover, Rosenblatt (1994) Transactional Model is used for teaching literary texts to help students understand the aesthetic and cognitive aspects of reading. In this model, when the readers transact with text, i.e., interact, the readers and the text are transformed since the text itself reveals different meanings with different readers or different contexts. Therefore, schema theory explains reading in terms of the relationship between input (readers' cognitive ability to understand), and output (readers' ability to communicate what they comprehend (An, 2011). The usefulness of the schema theory in teaching reading is that it helps teachers to explain to EFL students how to improve their reading skills through exposing them to reading experiences to raise their cognitive ability. The schema theory assists students to deal with the complexity of the reading process which involves understanding the relationship between the text system of ideas, the syntactical and semantic structures, the word meanings, and the internal system of the readers which reflects their cognitive ability to comprehend, process, interact, and interpret the text.

The second theory that makes the conceptual foundation of the current research is the Processing Information Theory. According to Miller (2011), technology allows processing information to help in understanding the cognitive processes of perception, recognition, thinking, remembering, imagining, reasoning, judging, and problem solving. These mental processes play a vital role in language acquisition, and explain how students use their short-term and long-term memory to store and retrieve information. Paivio's (1971) dual coding theory explains how verbal and non-verbal processing occurs simultaneously when the language system deals with linguistic input and output. Clark and Paivio (1991) identified three types of processing: representational, which is the direct activation of verbal or non-verbal representations; referential, which refers to the activation of the verbal system by the nonverbal system or vice-versa; and associative processing, referring to the activation of representations within the same verbal or nonverbal system. Therefore, the decoding of language symbols is an important skill in reading comprehension. When students identify words and symbols, they can develop the process of comprehension. Reading involves two essential processes: analyzing textual information, and using background knowledge and prior experience to foster inference.

The third theory is Krashen's $(1981 ; 1989 ; 1995)$ language theory. According to Krashen (1981) language learning requires developing a curriculum that fosters acquisition rather than mechanical learning. Krashen (1981) argued that language acquisition depends on helping students discover their innate language ability. Krashen (1995) identified some aspects relevant to language acquisition, including optimal acquisition, which students can achieve through comprehensible input, i.e. intensive teaching programs. Krashen (1995) argued that comprehensible input is the result of acquiring unfamiliar vocabulary during learners' experiences and practice of reading different texts. Krashen (1989) also used the term incidental acquisition of second language vocabulary to refer to learners' ability to increase their vocabulary, which adds to the comprehensible input. Another aspect of language acquisition is interesting or relevant input, which refers to the best practice that can occur when students acquire language skills through reading relevant and interesting topics. The third aspect of language acquisition is no grammatical sequencing of input, which explains how teachers can use teaching methodologies that focus on using functional grammar rather memorizing grammatical rules. The fourth aspect is quantity, not just quality, which emphasizes the immersion of experience for ESL and EFL students. The fifth aspect of language acquisition is affective filter, which refers to the figurative obstacles that hinder students from achieving their goals due to some negative emotions or attitude towards learning a foreign language. In the light of this theory, students can develop reading skills spontaneously through intensifying their reading practice. Interactive reading theories emerged from this view of assessing readers' responses to the text. For example, Goodman (1970), Rumelhart (1980; 1985), Smith (1982), Schwartz (1984), and Rosenblatt (1985), focused on the readers' background knowledge and experiences as a necessary factor in text interpretation.

\section{Literature Review}

The literature review presented herein is based on analyzing five main issues or concerns relevant to this study research questions. The first issue is the barriers that hinder students from achieving reading competence. The second issue deals with text types and reading strategies. The third concern is reading modes to examine the previous research findings regarding loud and silent reading, and general and inferential reading. The fourth issue is the application of technology in teaching reading. The fifth issue is the advantages of the linguistic integrative model. 


\subsection{Barriers to the Efficacy of Reading Proficiency}

Previous research (Anderson, 1993; Boatman, \& Long, 2010; Eskenazi \& Folk, 2015; Gruenbaum, 2012; Lai, Li, \& Amster, 2013; Lin \& Chen, 2006; Schwartz, 1984; Springer, Wilson, \& Dole, 2015; Thomas \& McDaniel, 2007) highlighted the problems that students faced in reading effectively, which included: a limited knowledge background about various topics; inability to process information; weak reading comprehension skills; failure to construct new knowledge; limited vocabulary; lack of reading strategies such speed, scanning, skimming, and summarizing; inability to infer the meanings; and limited interaction with the texts. Other barriers include students' attitudes and motivation, and ineffective teaching methodologies that foster higher order thinking. Yang and Han (2009), Springer, Wilson, and Dole (2015), Zhang (2009), and Zhong (2002) asserted that students who did not use critical thinking had weak comprehension skills, which resulted in inability to understand relationships among the units of the text, recognize contradictions, comparisons or analogies, or extract logical inferences. Gorzycki et al. (2016) indicated that students who did not achieve reading proficiency were those who were unable to perform cognitive tasks related to interpreting various texts. Moreover, Tang (2016) pointed out that English reading activities that required students to merely memorize and recite information did not help students develop critical thinking skills. Thomas and McDaniel (2007) argued that students' low comprehension was partially due to not using appropriate teaching techniques. Ineffective teaching methods did not prepare students to analyze and summarize, or predict sequence of events in the texts. Hence, using effective teaching methodologies is inevitable for motivating students to improve their reading levels.

\subsection{Text Types and Reading Strategies}

Successful reading strategies should focus on enhancing student's attention on the main ideas, asking students questions about their understanding to help them monitor their comprehension, and linking student's relevant prior knowledge to the new information. Reading strategies include techniques for fostering loud and silent reading, enhancing memory, processing, storing and retrieving information, deepening comprehension, summarizing, scanning and skimming, and understanding authors' intentions, tones, and purposes. Effective reading strategies should enable students to analyze the text textually, identify previous relevant knowledge, connect parts of the text together, recognize key words, and identify the problems that hinder comprehension. Teachers who provide useful reading strategies motivate students to increase their interest and comprehension level (Thomas \& McDaniel, 2007). Thus, teachers can integrate the reading strategies into cognitive teaching methods. Research (Beldarrain, 2006; Blomberg, 2011; Cooke et al., 2013; Deceased \& Shermis, 2003; Russ-Eft \& Preskill, 2009; Schunk, 2011; Wilson, 2005; Zhang, 2010) showed that cognitive approaches assisted students in conducting analytical studies of the texts to understand their phonological, morphological, stylistic, and semantic components. Research (Goldstein, 2014; Marzano \& Heflebower, 2011) argued that comprehending the meaning from the text, the reader should use some cognitive and meta-cognitive strategies to facilitate inferring the deep meanings. Extracting the meaning from the text involves understanding not only the information provided by the text, but also the relationships among ideas and units of the texts. Reading strategies are enhanced by practice, and students should be able to read different text types.

In this respect, Jakobson (2011), influenced by Buhler's (Buhler \& Goodwin, 2011) research of 1934 on the functions of the language, identified three main functions of the language: the expressive, the informative, and the vocative. The informative and the vocative functions are identified in objective texts such as academic textbooks and scientific articles while the expressive function is employed in subjective texts such as autobiographies, biographies, novels, short stories, poetry, and drama. Students should be aware that diverse genres of literature require different reading strategies. For example, literary texts such as novels and short stories require identification of two significant concepts, namely: leitmotifs and the author's keywords. However, reading poetry, needs knowledge about meter and rhyme. Another feature of a literary text is its semantic characteristics, and its emotive language, and connotations and denotations. Gee and Handford (2013), and Stubbs (2001) concluded that discourse prosody requires distinctive skills, knowledge, and mental abilities that allow readers to understand not only the syntactical components of the literary works, but also the implied meanings. Understanding aesthetic values depends on identifying some literary devices such as imagery, symbolism, and sound devices including rhymes and rhythms. A great deal in understanding literary texts relies on recognizing such devices as metaphors, similes, onomatopoeia, oxymorons, metonymies, and irony. Students should be trained to identify the function of the language, and grasp the implied meaning. On the other hand, scientific texts have different characteristics, including depersonalization and nominalization to convey precise and achieve objective information. According to Glasman (2010) scientific language is characterized by long sentences which contain a number of adjectives or nouns used as adjectives to provide a great deal of modification; excessive use of passives to emphasize impersonal ideas; and specialized vocabulary to 
communicate scientific facts. Therefore, reading strategies should guide students to identify such features to facilitate understanding the text contents.

\subsection{Reading Modes: Loud Vs. Silent Reading, General vs. Inferential Reading}

While there are many factors that impact comprehension, loud and silent reading modes are considered the most influential indicators of students' reading proficiency (Bell, 2004). Kwon and Linderholm (2015) argued that reading skill was highly correlated with reading speed, and that loud reading helped students improve pronunciation, which affected their understanding of the word. Wilson-Fowler and Apel (2015) asserted the positive relationship between loud reading, and reading speed. Loud reading helps students accelerate reading speed, which is essential for increasing time and quantity of reading. In this light, Dickens and Meisinger (2016) conducted a normative study using the Test of Word Reading Efficiency, and concluded that skills in word reading fluency improved through continuous loud reading practice. Eskenazi and Folk (2015) affirmed that loud, visual reading helped students to understand how the strategies of skimming and scanning are applied. On the other hand, Ari (2015) examined college readers' silent reading rate and their reading comprehension, and found a significant impact of silent reading on vocabulary, and information processing. Similarly, Jiang (2015) compared silent and loud reading modes, and found that silent reading improved students' comprehension significantly. Silent reading consolidated students' information processing capacity, and enhanced their understanding of inferences. Schmitt et al. (2011) argued that students acquired reading skills not only through loud reading, but also by listening to reading texts, which contributed to increasing their inferential reading ability. Snow and O'Connor (2016) confirmed that that inference was fostered through close reading when students were trained to extract the meaning, examining the linguistic levels of the text. Moreover, Bilikozen and Akyel (2014) indicated that close reading revealed students' variables of differences that impacted their reading comprehension, including prior knowledge, linguistic proficiency, motivation, and metacognitive skills. Tang (2016) concluded that close reading urged students to use their critical thinking to understand implied meanings, thus, fostered students' inferential reading skills. These studies asserted that students benefited from loud reading to improve reading speed, and from silent close reading to generate inferences, which enabled them in synthesizing and predicting deep meanings.

\subsection{The Application of Technology in Teaching Reading Comprehension}

Reading instruction that incorporates technology makes use of digital media, information technology, and software packages. New concepts about teaching reading emerged because of the availability of new literacies via the Internet (Warschauer, 2006). The new literacies include: innovative text formats such as multimedia and hybrid texts; new readers who practice reading nonlinearly; new reading devices such as kindle, e-reader, and iPad; effective search engines to locate information; and online dictionaries, encyclopedias, and grammar e-books, and websites that provide all types of reading materials. These technologies affect students' reading competence. The conventional books are no longer the only source of information, and using e-book, and text to speech software, made reading faster and cost effective. For example, using iPads in reading can help in increasing knowledge transfer. The feature of scrolling through parts of the text, instead of reading mechanically page by page, allowed learners to access various sources outside the text to facilitate the process of comprehension. The online resources such as libraries, and websites, can enhance students' cognitive abilities, and this in turn leads to increasing reading competence. Gartner (2011) identified a number of computer technologies that affected learners' competence, such as cloud computing, mobile applications, media tablets, and social media platforms. These platforms serve as cognitive models for teaching. Chen et al. (2016) highlighted the attributes of computers and software that support reading. For example, digital technologies can be integrated with printed textbooks. Some examples include DPPIP (digital pen and paper interaction platform), iBELLEs (interactive Blended English Language Learning Enhancement system), and MOODLE (modular, object-oriented dynamic learning environment), which are used as course management systems to support English-language learning and teaching. Moreover, Okada and Sakamoto (2015) argued that lesson plans, teaching styles, and classroom were successfully adopted based on real-time interactions for reading courses. Using iBELLEs played a significant role in bridging the gaps between teachers' expectations and students' needs because iBELLEs built a database of electronic textbooks with multidimensional communication to boost students' learning. In the same study, Web OCM next, a Language Management System (LMS), proved to be very effective in providing simultaneous feedback from students that helped teachers design new lessons for the EFL reading classrooms. Furthermore, Tsai et al. (2016) applied the technology of data mining to mine students' reading errors, and concluded that by using this technology, teachers were able to design reading materials to not only facilitate learning outcomes, but also reduce the cost of books. Thus, the pedagogical implications of integrating technology into linguistic approaches require educators' attention at higher education. 


\subsection{The Advantages of the Linguistic Integrative Model}

For building comprehension skills, Linderholm et al. (2014) argued that integrating cognitive approaches into teaching reading comprehension helped students to reinforce mental activities of analyzing and reconstructing the text information coherently. Teachers need to know that for students to become successful readers, teaching strategies should include cognitive approaches to identify students' potentials for acquiring advanced reading skills. Reid (2013) argued that integrating technology, such as digital texts, into teaching techniques contributed to students' progress. Digital texts were more appealing to college students and this motivated them to increase their reading activities. The study also showed that digital texts played an important role in fostering students' comprehension skills and metacognitive awareness. In this respect, Shang (2015) examined the effect of hypertexts on scaffolding EFL reading comprehension, and found a significant difference in the comprehension scores of those students who used hypertext-based reading. Kissau and Algozzine (2015) indicated that the mode of instructional delivery had an impact on self-efficacy. Chen et al. (2016) showed that Web- or computer-based reading technologies provided interactive digital materials that fostered English oral reading fluency using repeated reading strategy. In harmony with these studies, Wright, Fugett, and Caputa (2013) confirmed that the linguistic approach of integrating the Internet as a source for e-reading, resulted in increasing students' vocabulary and reading scores, and enhancing students' engagement in the reading process. Chen et al. (2013) also confirmed that the effects of e-books, on students' reading attitude, comprehension, and vocabulary, were significant. Barone and Wright (2008) concluded that $72 \%$ of the students exceeded the benchmark criteria for English language because teachers used the integrative approach in the classrooms. The bottom line is that previous research showed that while conventional teaching techniques were ineffective in helping students improve their reading skills, the linguistic technology-based integrative approach was more successful in motivating students to develop reading competence.

\section{Research Method}

This quantitative correlational research aimed at examining the statistical relationship between the linguistic integrative teaching model and college students' reading competence. The study occurred in four phases: (1) observing four reading classes of 100 students to gather data on teachers' teaching methodologies; (2) using a Likert scale questionnaire to identify the problems that affect students' English reading performance; (3) conducting a reading comprehension exam to determine the reading level of the whole sample; (4) carrying out experimental training sessions for 35 students selected randomly from the same sample to be taught using the linguistic integrative model, for 5 weeks: and (5) administering another comprehension test at the end of the fifth week, to measure the experimental group reading level statistically.

\subsection{Research Questions}

1) What is the statistical significant difference between the experimental group reading scores before and after the training period of using the linguistic integrative teaching model?

2) What are the impacts of using the linguistic integrative model on students' reading competence?

3) What is the process of using the linguistic integrative model in reading classrooms?

\subsection{Research Hypothesis}

There is a relationship between the linguistic integrative model and students' reading competence. The Null Hypothesis is: There is no relationship between the linguistic integrative model and students' reading competence.

\subsection{Instrumentation}

The current study instruments included a Likert scale questionnaire of 21 items; and a reading comprehension pre-test and post-test. The tests were adopted from ACCUPLACER, which is an integrated computer-based assessment designed to evaluate students' reading skills. The test is originally designed by Board College in USA (2016), which is a specialized agency in college students' exams. The reading exam covers six skills: (1) understanding the text purpose and tone; (2) identifying the central ideas; (3) recognizing supporting details; (4) understanding sentences and vocabulary relationships; (5) distinguishing illustration, comparison and contrast and cause and effect relationships; and (6) understanding inferential meanings. The test that was designed for this study contained 5 texts, selected from various sources, including encyclopedia Americans, and literature books. The 5 texts covered literary and non-literary topics, including literary works, history, geography, information technology, and education. The selected texts required previous background knowledge. Each text was followed by 10 comprehension questions, and 10 multiple-choice format questions, focused on identifying word meaning, syntactical and semantic relationships, implicature, and inference. 


\subsection{Participants' Characteristics}

The sample of this study consisted of 100 undergraduate female students, selected randomly from freshmen students from at College of Languages and Translation at IMAMU University, Saudi Arabia. The majority of the students, with the percentage of $80 \%$ were within the age category of 22 to 25 years old while $20 \%$ were within the age category of $18-20$ years old. Moreover, $55 \%$ of the students were married while $45 \%$ were single. All students studied English at preparatory and secondary schools for 6 years prior to their college study. Only 21\% of the participants read on a daily basis external texts that were not required in their curriculum. The percentage of the participants who used computers for academic reading was only $32 \%$ although $80 \%$ used computers for social media communications.

\subsection{Procedure, Data Collection and Analysis}

An initial assessment was conducted, using a Likert scale questionnaire to identify the participants' reading problems. A pilot study was conducted for achieving validity. The participants responded to the questionnaire items in class after reading the consent form. The software SPSS was used for data analysis. The 100 participants took the reading comprehension test, then 35 participants were selected to be involved in a reading class that was taught implementing the linguistic integrative approach for 5 weeks ( 3 hours per session, 3 times a week). The 35 participants were selected based on their scores in the first reading comprehension test. The participants' scores were classified into 3 groups: $75-65 \% ; 64-55 \%$, and $54-45 \%$, representing the highest, the intermediate, and the weakest scores. During the 5 week training, this experimental group was exposed to the treatment which encompassed reading loudly and silently to improve speed, pronunciation, and reading comprehension. The group also was taught reading strategies, including scanning, skimming, and summarizing, and inference. The linguistic cognitive model, employed in the experimental class integrated reading schema theory, linguistic reading theories, Krashen's $(1981 ; 1989 ; 1995)$ language theory, and information processing theory. The technology used in the class focused on using the participants' kindle tablets, or personal computers when they downloaded the kindle application. The Internet and Prezi presentations that incorporated videos for reading demonstration were also used. The advantage of the kindle tablets is that they provide hypertexts, podcasts, video casts, in-built dictionaries and thesaurus, and access to the web sites. The websites access functioned as external resources for increasing the participants' knowledge about the topics they were reading. Another advantage of kindle is using multi colors bookmarkers to highlight important information. The kindle tablet is also linked to word processing documents which allow users to take notes and write summaries. After the training was given, the reading comprehension post-test was administered for the same group to compare their scores before and after the experiment. To conduct an objective comparison between the participant's performance before and after the training, data was analyzed using inferential statistics to measure the participants' reading competence progress.

\section{Results}

Data analysis showed that the students had problems in loud and silent reading, reading speed, critical and inferential reading, vocabulary and word recognition, and decoding the texts' messages, which reflected students' weak reading skills. The study also pointed to the ineffective traditional teaching strategies as the main cause of this problem. The findings of the present study were consistent with the results of previous studies which investigated the same topic. The participants' profiles revealed their reading level, and the extent of their satisfaction with the teaching methods employed in their reading classes at the college. Based on the GPA scores, the percentage of the participants with advanced reading level reached $21 \%$. The advanced level refers to scores between $99-85$ out of 100 . The percentage of the participants with intermediate reading level reached $56 \%$. The intermediate level points to language scores between $84-70$ out of 100 . The percentage of the participants with beginner reading level reached $23 \%$. The beginner level refers to scores between 69-60 out of 100. Data analysis also indicated the participant's reading problems. Figure 1 displays the results. 


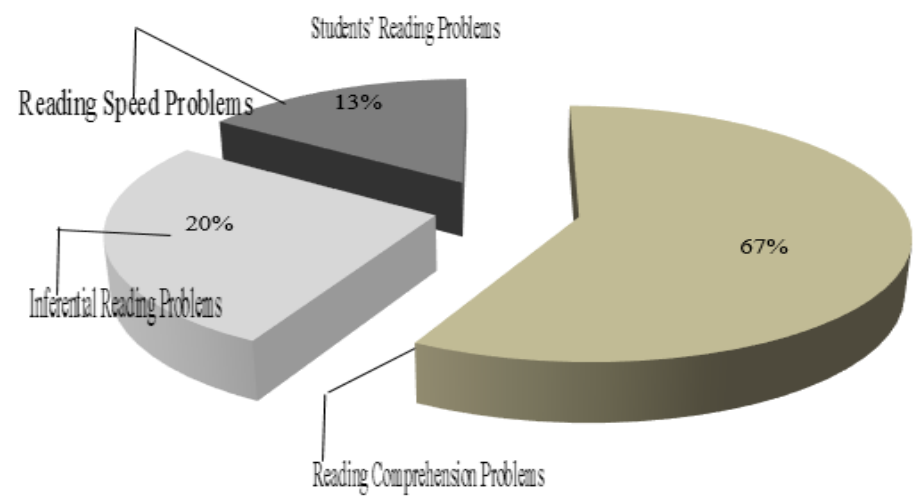

Figure 1. Students' reading problems prior to applying the integrative model

As shown in Figure 1, the participants' reading problems were revealed in three main areas which consisted of reading comprehension, with the percentage of $67 \%$, and reading speed, with the percentage of $13 \%$. The inferential reading problems reached $20 \%$. In addition, data analysis showed the participants' degree of satisfaction regarding the methodologies used in teaching reading. Figure 2 shows the results.

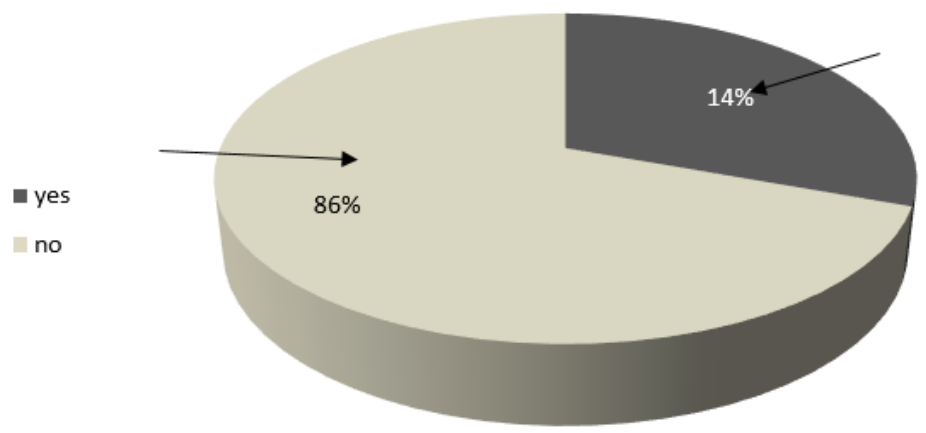

Figure 2. Students' opinions about teaching reading prior to training

Figure 2 indicates that the percentage of students, who were not satisfied with the traditional teaching methods employed in the reading classrooms, pointed to $86 \%$. Only $14 \%$ of the participants were comfortable being taught through general lectures and rote learning. Furthermore, data analysis of the questionnaire items also reflected that the teaching methodologies currently used did not provide students with strategies to solve the problems they encountered while reading various types of texts. The cumulative percentage of students who always acquired reading strategies from the traditional teaching methods reached only $22 \%$ while the percentage of students who sometimes learned reading strategies from their current classrooms reached $31 \%$, and the percentage of students who frequently learned reading strategies from their classes was $21 \%$. Such results were also reflected in students' responses regarding their abilities to conduct text analysis to identify its syntactic, semantic and pragmatic functions. The cumulative percentages of students' capabilities for analyzing and synthesizing the text referred to only $21 \%$ of students who could always conduct this analysis. Such results showed the necessity for conducting the present study to provide some appropriate solutions to help students improve their reading skills.

To validate the hypothesis there is a relationship between the linguistic integrative model and students' competence in reading, data analysis showed a statistical significance at the level of 0.1 , as the 2 -tailed significant is less than 0.1 and the $t$ values of the items exceed that of $\mathrm{df}$ (99), which is 2.6264. Thus, the null hypothesis was rejected. The results of the paired $t$-test analysis indicated a statistical significance at the level of 0.5 as the two-tailed p-value, which was 0.001 , is less than 0.5 ; and the $t$-value of items, which was 7.884 , exceeded that of 2.776 at the level of 0.5 . The inferential reading skills of the experimental group before using 
the linguistic integrative model was $t=-0.46, \mathrm{p}>0.05$, and after using the linguistic integrative model was $t=0.48$, $p>0.05$. The statistical report includes frequencies and percentages for identifying the sample characteristics. The correlation coefficient was used to calculate the internal consistence of the questionnaire. Table 1 displays the statistical significance.

Table 1. The questionnaire statistical significance

\begin{tabular}{lllll}
\hline Q & T & Df & Sig. (2-tailed) & Mean Difference \\
\hline Q1 & 34.561 & 99 & .000 & 3.920 \\
Q2 & 41.295 & 98 & .000 & 3.949 \\
Q3 & 31.446 & 96 & .000 & 3.567 \\
Q4 & 33.887 & 99 & .000 & 3.690 \\
Q5 & 44.705 & 98 & .000 & 3.909 \\
Q6 & 39.228 & 99 & .000 & 3.810 \\
Q7 & 33.875 & 98 & .000 & 3.798 \\
Q8 & 33.798 & 99 & .000 & 3.480 \\
Q9 & 31.975 & 98 & .000 & 3.586 \\
Q10 & 34.370 & 99 & .000 & 3.640 \\
Q11 & 37.265 & 98 & .000 & 3.859 \\
Q12 & 39.463 & 98 & .000 & 3.717 \\
Q13 & 39.974 & 96 & .000 & 3.753 \\
Q14 & 38.575 & 97 & .000 & 3.735 \\
Q15 & 33.286 & 97 & .000 & 3.490 \\
Q16 & 32.576 & 97 & .000 & 3.480 \\
Q17 & 36.753 & 96 & .000 & 3.722 \\
Q18 & 36.156 & 97 & .000 & 3.643 \\
Q19 & 33.390 & 96 & .000 & 3.588 \\
Q20 & 34.167 & 96 & .000 & 3.670 \\
Q21 & 22.825 & 97 & .000 & 3.245 \\
\hline
\end{tabular}

Table 1, shows that there is a statistical significance at the level of 0.1 where the values exceed 2.6264 . Additionally, data analysis also showed the challenges that the experimental group faced before and after using the linguistic integrative model. Table 2 displays the results.

Table 2. The participants' scores in reading before and after using integrating technology

\begin{tabular}{llll}
\hline Problems & $\begin{array}{l}\text { Before Using } \\
\text { Technology }\end{array}$ & $\begin{array}{l}\text { After Using } \\
\text { Technology }\end{array}$ & $\begin{array}{l}\text { Percentage of } \\
\text { Progress }\end{array}$ \\
\hline Comprehension & & $67 \%$ & $34 \%$ \\
Reading Speed & $18 \%$ & $45 \%$ & $27 \%$ \\
Analysis skills & $29 \%$ & $82 \%$ & $53 \%$ \\
Inference Ability & $34 \%$ & $87 \%$ & $53 \%$ \\
Vocabulary & $42 \%$ & $88 \%$ & $46 \%$ \\
Reading Literary Texts & $28 \%$ & $68 \%$ & $40 \%$ \\
Reading Non-Literary Texts & $19 \%$ & $52 \%$ & $33 \%$ \\
Knowledge Background & $20 \%$ & $63 \%$ & $43 \%$ \\
Reading Interaction skills & $32 \%$ & $72 \%$ & $40 \%$ \\
\hline
\end{tabular}

Table 2 shows the experimental group scores of the reading comprehension test before and after the treatment, and the percentage of progress. The highest percentage of these scores was the ability for inferring meaning from the texts, reaching $87 \%$ while the lowest percentage was the scores of reading speed with $45 \%$. The problems of comprehension, reading speed, analysis, inference, vocabulary, reading literary text, reading non-literary texts, knowledge background, and reading interactions were reduced after the treatment, showing progress percentage of $34 \%, 27 \%, 53 \%, 53 \%, 46 \% 4 \%, 33 \%, 43 \%$, and $40 \%$ respectively. Figure 3 displays the participants' results of reading textual analysis. 


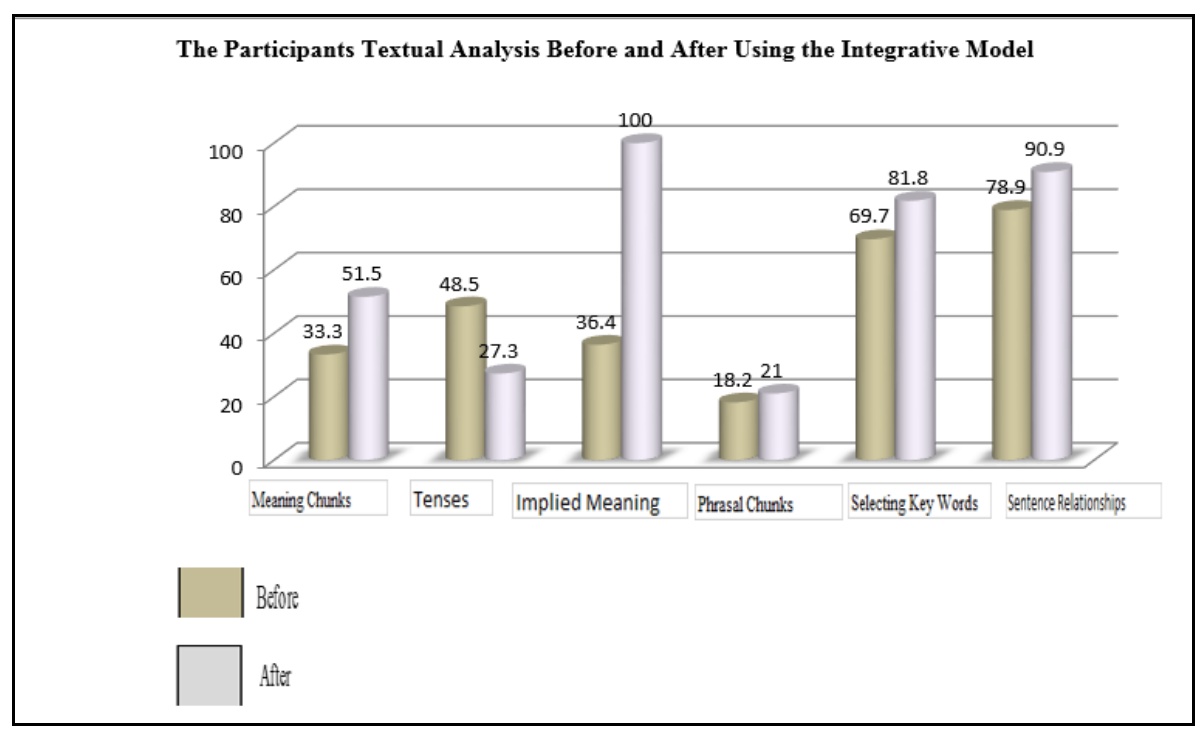

Figure3. The results of textual analysis before and after applying the integrative model

Figure 3 shows the experimental group results regarding their scores in the textual analysis of the reading text before using the linguistic integrative model and after using it. The highest percentage was in the area of implied meaning, reaching $100 \%$ after using technology while it was $36.4 \%$ employing the conventional technique; thus achieving improvement by $63.6 \%$. The percentage of the area of analyzing the meaning chunks was $33.3 \%$ before using technology and $51.5 \%$ after using technology. The percentages of the analysis of meaning chunks, phrases chunks, selecting keywords, and sentence relationships were $33.3 \%, 48.5 \%, 18.2 \% 69.7 \%, 78.9 \%$ respectively before using technology, and $51.5 \%, 21 \%, 81.8 \%$, and $90.9 \%$ respectively after using technology. The percentage of the analysis of tenses was the lowest before using technology, reaching $27.3 \%$ while it was $48.5 \%$ using traditional teaching methods, emphasizing, thus students' highest interest in memorizing grammatical rules. Figure 4 shows the participants' means and standard deviations, and areas of interest before and after using technology. 


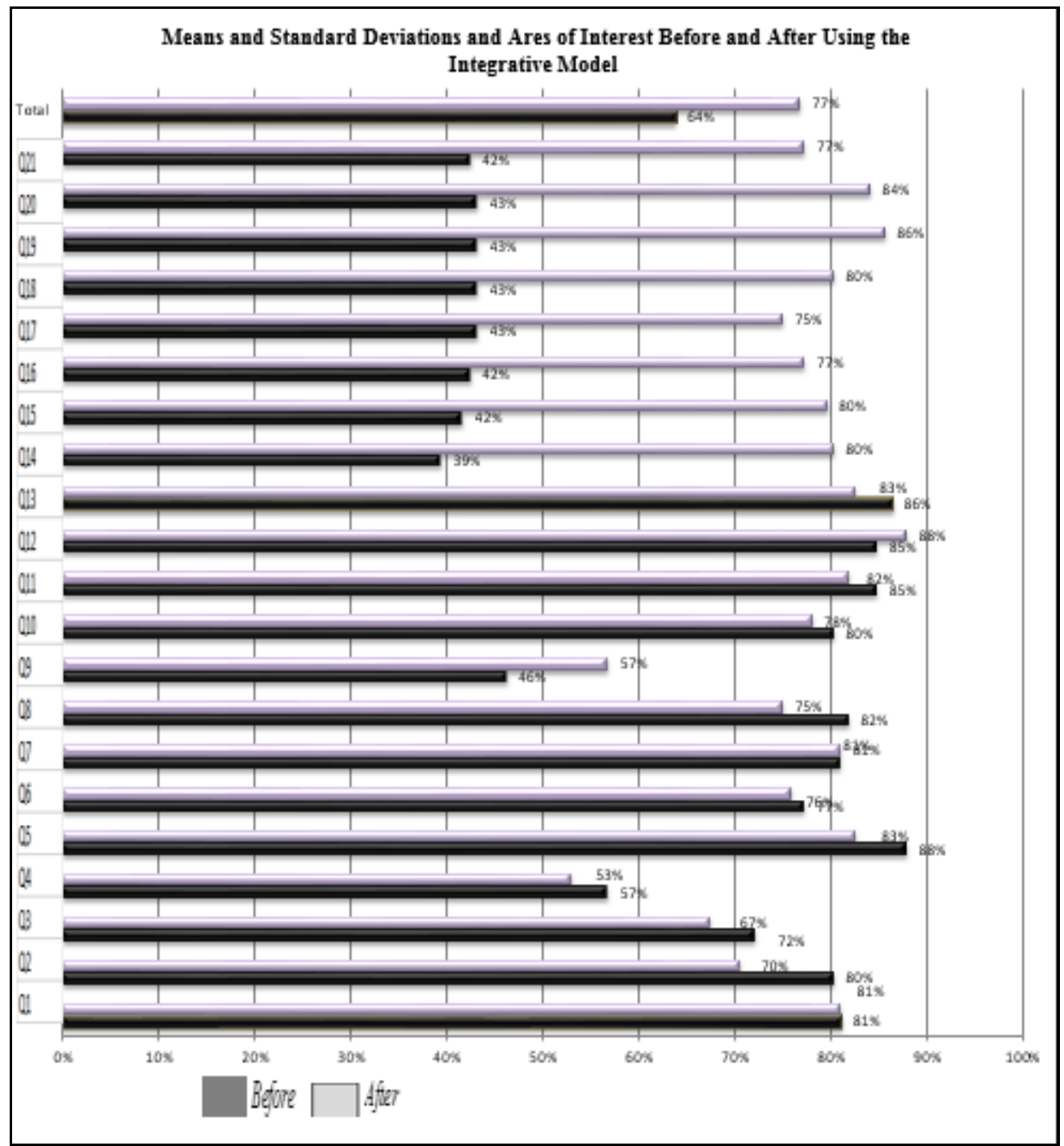

Figure 4. A statistical comparison of means and standard deviations and relative importance

Figure 4 displays a comparison of means and standard deviations of the experimental group before and after using the linguistic integrative model. The percentage of the questions from 14 to 21 was reading comprehension questions focusing on inferential meaning, reaching $39 \%, 42 \%, 42 \%, 43 \%, 43 \%, 43 \%, 43 \%, 42 \%$ respectively, before employing the linguistic integrative model, and $80 \%, 80 \%, 75 \%, 80 \%, 86 \%, 84 \%$ respectively, after using the linguistic integrative model. The percentages of the areas of grammatical sentence analysis that required grammatical rules did not show a significant difference.

\section{Discussions and Recommendations}

Based on data analysis results, the main problems that students encountered in reading were: understanding the inferential meanings of the text; recognizing supporting information; understanding the author's intention; identifying text types based on the function of the language. The pre and post reading comprehension test, proved to be an effective assessment tool. The first type of question which consists of a reading passage followed by questions about the text, revealed students' level in reading comprehension. The reading passages focused on revealing the participants' understanding of explicit and implicit statements related to the main ideas. The second type of questions in the test focused on identifying word meaning, and sentence relationships to show the participants' knowledge of syntactical, semantic, and lexical structures of the text. The results of the assessment, in conjunction with students' academic background, academic objectives, and interests, showed that the integration of technology in the reading classroom motivated students to improve their reading skills. Students were more interested in improving their general knowledge regarding various topics, which helped them to gain 
reading experiences. Regarding the current study research questions, data analysis indicated a significant statistical relationship between the linguistic integrative model and students' reading scores. The participants' percentage of improvement before and after using the linguistic integrative model was $34 \%$ for comprehension, $24 \%$ for reading speed, $53 \%$ for analysis skills, and $53 \%$ for inference skills. In conjunction with the second research question, the linguistic integrative model proved to have a positive impact on students' reading competence. Students not only improved in their test scores, but they also developed their ability to read literary and non-literary texts as data analysis showed improvement by $33 \%$ and $43 \%$ respectively. Students also improved their interactions with the texts by $40 \%$. The participants were able to recognize word meaning, and were able to improve their vocabulary by $46 \%$. Such results indicated that traditional teaching strategies which depended on general lectures and explaining the mechanical structure of the reading texts did not help students use their cognitive abilities to improve their reading comprehension. The advantages of integrating technology into the linguistic theories provided new perspectives for teaching reading. The linguistic integrative model helped students to understand the systems of their thinking and how important was their prior knowledge to comprehend new ideas. Students also became able to differentiate between the expressive and the informative functions of the text language, which helped them to discern empirical ideas, relational ideas, and inferential meaning, and symbolic references. The application of technology improved students' anticipations of perception, and meta-comprehension ability as they became able to reflect on their own thinking. Another advantage of implementing the linguistic integrative model is that it urges students to gain more reading experiences, which is crucial for improving their reading competence. Using these findings, the researcher made the following recommendations: integrate educational technology into teaching the reading courses at the college; provide professional programs for teachers to train them to use the linguistic integrative approaches; and provide linguistic laboratories that are equipped with modern technologies, including reading software, to intensify students' reading practices. Figure 5 displays the process of implementing the linguistic integrative model.

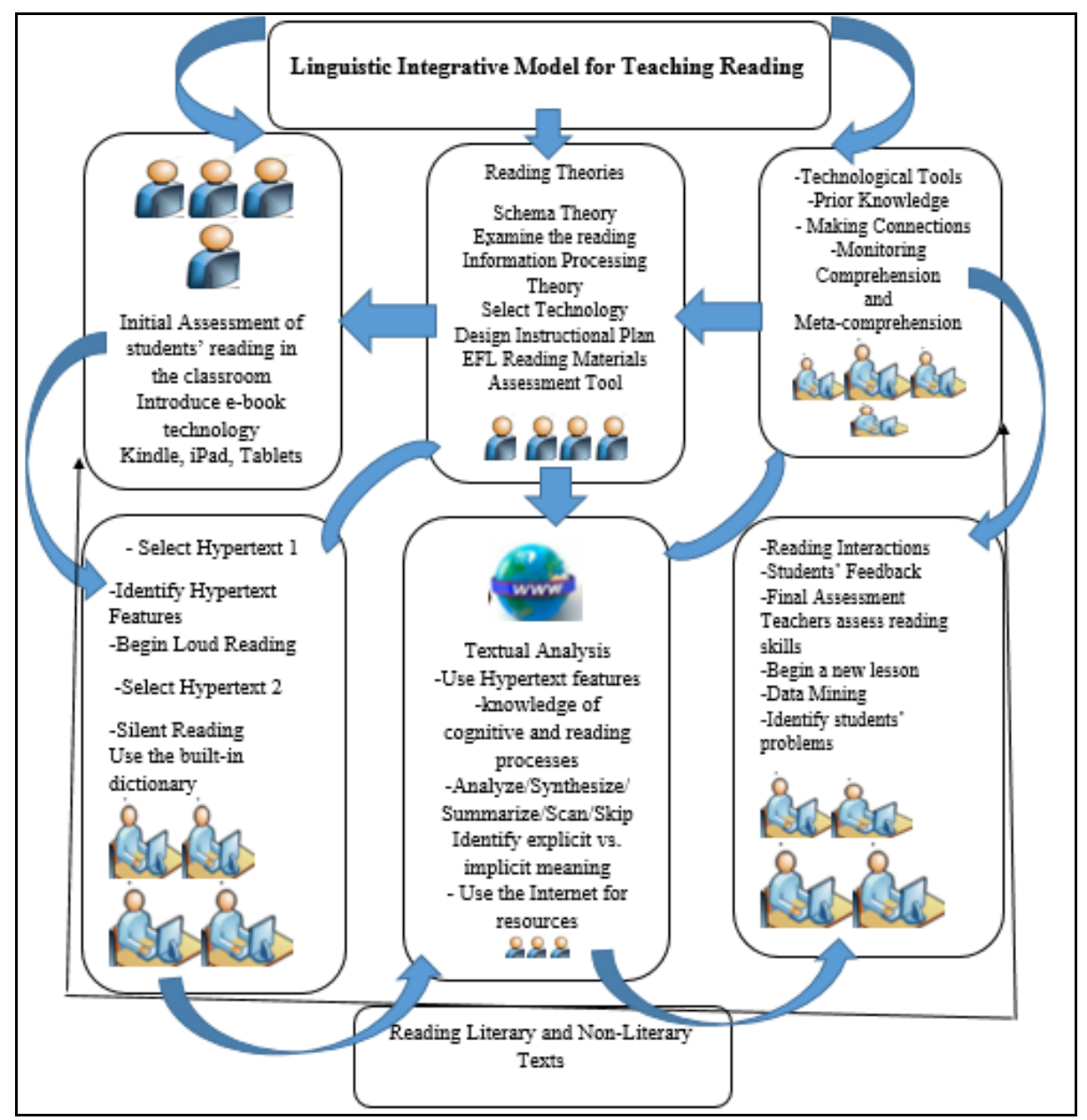

Figure 5. A linguistic integrative model

As displayed in Figure 5, the linguistic integrative model is based on integrating technology into reading theories to teach reading skills. The procedure of implementing this model includes selecting the reading theory that the 
teacher aims at using as a source for reading strategies; making a list of the reading strategies stated in the theory; selecting the reading hypertexts and locating them on the e-book device, such as kindle; preparing a number of comprehension exams based on the selected texts; checking the language laboratory machines; and giving students instructions on how to use the e-reading devices. Each lesson begins with introducing a few reading strategies, then move to continual practice of reading using the features of hyper linking to help students improve their vocabulary, and background knowledge. With students' progress, teachers can focus on giving instruction on textual and contextual analysis. Reading strategies should include loud reading, using text to speech software to help students improve pronunciation, and speed, and silent reading, using the hypertext features of bookmarking, in built dictionaries, and hyperlinks to website resources. Teachers can integrate project-based, workshop-based, and apprenticeship methods while integrating the reading technology. The Internet provides numerous web-based tools and resources to support teachers in their efforts to motivate students.

\section{Conclusion}

The present study examined the impact of implementing a linguistic integrative teaching model on college students' reading competence. Since reading is a complex process with overlapping skills, it requires a multidimensional approach that modern technology offers. This study concluded that ineffective traditional teaching methodologies impacted the EFL students' reading performance negatively. Technology can help teachers to design linguistic settings to make language learning dynamic and effective. Language teachers can incorporate modern technologies into reading theories to provide students with the most appropriate strategies that can foster their reading capacity. This study gives evidence that there is a statistical relationship between technology-based linguistic approaches and students' reading competence. Students can improve not only their reading strategies in terms of comprehension, speed, scanning, skimming, and summarizing, but they can also improve their critical thinking to conduct thorough textual analysis of various types of texts. The significance of the study is that it provides the integrative linguistic model that the researcher designed to be implemented at higher education. The model is based on integrating hypertext devices, e-books, and web resources into reading theories to teach reading skills. Using kindle devices, computers, or iPads, the linguistics integrative model can assist students to improve their attitude and motivation towards reading. However, conducting training programs to prepare teachers to integrate technology into teaching is necessary so that they can employ cognitive and metacognitive teaching methods. Equipping the classrooms with linguistic laboratories, e-reading devices, and reading software is also essential for applying the integrative model. The current study also highlights the implications of integrating technology in improving students' meta-comprehension, inferential reading, and reading interactions. Hence, this study is a contribution in teaching reading at higher institutions, reinforcing their roles in the society, preparing students to become competent readers who can develop their mental and social abilities.

\section{References}

Ahmadi, M. R., Ismail, H. N., \& Abdullah, M. K. (2013). The importance of metacognitive reading strategy awareness in reading comprehension. English Language Teaching, 6(10), 235-244. http://dx.doi.org/10.5539/elt.v6n10p235

An, F. C. (2011). Schema theory and language comprehension. Journal of Language and Literature Studies, 2, 4-7.

Anderson, J. R. (1993). Problem solving and learning. American Psychologist, 48(1), 35. http://dx.doi.org/10.1037/0003-066X.48.1.35

Anderson, N. J. (1999). Exploring second language reading: Issues and strategies. USA: Heinle \& Heinle Publishers.

Ari, O. (2015). Fluency gains in struggling college readers from wide reading and repeated readings. Reading Psychology, 36(3), 270-297. http://dx.doi.org/10.1080/02702711.2013.864361

Barone, D., \& Wright, T. E. (2008). Literacy instruction with digital and media technologies. The Reading Teacher, 62(4), 292-302. http://dx.doi.org/10.1598/rt.62.4.2

Bartlett, F. C. (1985). Thinking: An experimental and social study. London: Allen \& Unwin.

Beldarrain, Y. (2006). Distance education trends: Integrating new technologies to foster student interaction and collaboration. Distance Education, 27(2), 139-153. http://dx.doi.org/10.1080/01587910600789498

Bell, S. (2004). Transforming seniors who don't read into graduates who do. English Journal, 93(5), 36-40. http://dx.doi.org/10.2307/4128933 
Bilikozen, N., \& Akyel, A. (2014). EFL reading comprehension, individual differences and text difficulty. Reading Matrix: An International Online Journal, 14(2), 263-296.

Blomberg, O. (2011). Concepts of cognition for cognitive engineering. International Journal of Aviation Psychology, 21(1), 85-104. http://dx.doi.org/10.1080/10508414.2011.537561

Boatman, A., \& Long, B. T. (2010). Does remediation work for all students? How the effects of postsecondary remedial and developmental courses vary by level of academic preparation. New York: National Center for Postsecondary Research.

Brandom, R. (1998). Making it explicit. Cambridge, MA: Harvard University Press.

Buhler, K., \& Goodwin, D. F. (2011). Theory of language: The representational function of language. New York: John Benjamins Publishing Company.

Carrell, P. L. (1984). Evidence of a formal schema in second language comprehension. Language Learning and Communication, 2, 87-112. http://dx.doi.org/10.1111/j.1467-1770.1984.tb01005.x

Carrell, P. L., \& Eisterhold, J. C. (1983). Schema Theory and ESL reading Pedagogy. TESOL Quarterly, 19, 81-92.

Chen, C., Tan, C., \& Lo, B. (2016). Facilitating English-Language learners' oral reading fluency with digital pen technology. Interactive Learning Environments, 24(1), 96-118. http://dx.doi.org/10.1080/10494820.2013.817442

Chen, N., Chen, S., Chen, S. H., \& Shyh, C. (2013). The effects of extensive reading via e-books on tertiary level EFL students' reading attitude. Reading comprehension and vocabulary. TOJET: The Turkish Online Journal of Educational Technology, 12(2), 1-10.

Clark, J. M., \& Paivio, A. (1991). Dual coding theory and education. Educational Psychology Review, 3(3), 149-170.

College Board. (2016). ACCUPLACER tests. Retrieved from https://www.collegeboard.org/

Cooke, N. J., Gorman, J. C., Myers, C. W., \& Duran, J. L. (2013). Interactive team cognition. Cognitive Science, 37(2), 255-285. http://dx.doi.org/10.1111/cogs.12009

Deceased, L. M. B., \& Shermis, S. S. (2003). Learning theories for teachers (6th ed.). New York: Allyn \& Bacon.

Dickens, R. H., \& Meisinger, E. B. (2016). Examining the effects of skill level and reading modality on reading comprehension. Reading Psychology, 37(2), 318-337. http://dx.doi.org/10.1080/02702711.2015.1055869

Douglas, K., Barnett, T., Poletti, A., Seaboyer, J., \& Kennedy, R. (2016). Building reading resilience: Re-thinking reading for the literary studies classroom. Higher Education Research and Development, 35(2), 254-266. http://dx.doi.org/10.1080/07294360.2015.1087475

Dreyer, C., \& Nel, C. (2003). Teaching reading strategies and reading comprehension within a $\begin{array}{lllll}\text { technology-enhanced } \quad \text { learning } & \text { Syvironment. }\end{array}$ http://dx.doi.org/10.1016/s0346-251x(03)00047-2

Eskenazi, M. A., \& Folk, J. R. (2015). Reading skill and word skipping: Implications for visual and linguistic accounts of word skipping. Journal of Experimental Psychology: Learning, Memory, and Cognition, 41(6), 1923-1928. http://dx.doi.org/10.1037/xlm0000156

Gartner Inc. (2011). Top strategic technologies for 2011. Gartner Symposium/ITxpo. Retrieved from http://www.gartner.com/technology/symposium/?nicam=vsymww

Gee, J. P., \& Handford, M. (2013). The Routledge handbook of discourse analysis. New York: Routledge.

Glasman, H. (2009). Science research writing for non-native speakers of English. London: Imperial College Press.

Goldstein, E. B. (2014). Cognitive psychology: Connecting mind, research and everyday experience (4th ed.). CA: Belmont, Wadsworth Publishing.

Goodman, K. S. (1970). Behind the eye: what happens in reading. In K. S. Goodman \& O. S. Niles (Eds.), Reading: Process and program. Urbana, IL: National Council of Teachers of English.

Gorzycki, M., Howard, P., Allen, D., Desa, G., \& Rosegard, E. (2016). An exploration of academic reading proficiency at the university level: A cross-sectional study of 848 undergraduates. Literacy Research and 
Instruction, 55(2), 142-162. http://dx.doi.org/10.1080/19388071.2015.1133738

Gredler, M. (2009). Learning and instruction: Theory into practice (7th ed.). Upper Saddle River, NJ: Prentice Hall.

Grgurović, M., Chapelle, C., \& Shelley, M. C. (2013). A meta-analysis of effectiveness studies on computer technology-supported language learning. ReCALL, 25(2), 165-198. http://dx.doi.org/10.1017/s0958344013000013

Gruenbaum, E. A. (2012). Common literacy struggles with college students: Using the reciprocal teaching technique. Journal of College Reading and Learning, 42(2), 110-116. http://dx.doi.org/10.1080/10790195.2012.10850357

Han, J., Kamber, M., \& Pei, J. (2012). Data mining: concepts and techniques. Boston, MA: Morgan Kaufmann Publishers.

Hendricks, K. (2013). Reading and test taking in College English as a second language students. ProQuest LLC, Ph.D. Dissertation, Syracuse University. Retrieved http://www.proquest.com/en-US/products/dissertations/individuals.shtml

Jakoboson, R. (2011). Fundamentals of language. Charleston, Sc: Nabu Press.

Jiang, Y. (2015). Chinese college students' English reading comprehension in silent and loud reading-mode. English Language Teaching, 8(4), 24-30.http://dx.doi.org/10.5539/elt.v8n4p24

Kant, I. (1781). The critique of pure reason. New York: St. Martin's Press, Macmillan.

Kissau, S., \& Algozzine, B. (2015). The impact of mode of instructional delivery on second language teacher self-efficacy. ReCALL, 27(2), 239-256. http://dx.doi.org/10.1017/s0958344014000391

Krashen, S. (1981). Second language acquisition and second language learning. New York: Pergamon Press.

Krashen, S. (1989). The input hypothesis: Issues and implications. New York: Longman Group Limited.

Krashen, S. (1995). Principles and practice in second language acquisition. New York: Phoenix.

Kwon, H., \& Linderholm, T. (2015). Reading speed as a constraint of accuracy of self-perception of reading skill. Journal of Research in Reading, 38(2), 159-171. http://dx.doi.org/10.1111/1467-9817.12013

Lai, S., Li, C., \& Amster, R. (2013). Strategically smart or proficiency-driven? An investigation of reading strategy use of EFL college students in relation to language proficiency. Contemporary Issues in Education Research, 6(1), 85-92. http://dx.doi.org/10.19030/cier.v6i1.7606

Lin, C. C. (2010). "E-Book Flood" for changing EFL learners. US-China Education Review, 7(11), 36-43.

Lin, H., \& Chen, T. (2006). Decreasing cognitive load for novice EFL learners: Effects of question and descriptive advance organizers in facilitating EFL learners' comprehension of an animation-based content lesson. System, 34, 416-431. http://dx.doi.org/10.1016/j.system.2006.04.008

Linderholm, T., Therriault, D. J., \& Kwon, H. (2014). Multiple science text processing: Building comprehension skills for college student readers. Reading Psychology, 35(4), 332-356. http://dx.doi.org/10.1080/02702711.2012.726696

Madkour, M. (2011). Multiple intelligences and language acquisition: A qualitative study and application of Howard Gardner's theory of multiple intelligences. New York: Barnes \& Nobles.

Marzano, R. J., \& Heflebower, T. (2011).Teaching and assessing 21st century skills: The classroom strategies series. IN: Bloomington: Marzano Research Laboratory.

Miller, P. H. (2011). Theories of developmental psychology. New York, NY: Worth.

Mishra, J. (2014). Factors related to sight-reading accuracy: A meta-Analysis. Journal of Research in Music Education, 61(4), 452-465. http://dx.doi.org/10.1177/0022429413508585

O'Sullivan, M. K., \& Dallas, K. B. (2010). A collaborative approach to implementing 21st century skills in a high school senior research class. Education Libraries, 33(1), 1-9.

Okada, T., \& Sakamoto, Y. (2015). Dynamic lesson planning in EFL reading classes through a new e-learning system. Research-publishing.net. Paper presented at the 2015 EUROCALL Conference (22nd, Padova, Italy).

Paivio, A. (1971). Imagery and verbal processes. New York: Holt, Rinehart \& Winson.

Reid, A. J. (2013). Improving metacomprehension and calibration accuracy through embedded cognitive and 
metacognitive strategy prompts. ProQuest LLC, Ph.D. Dissertation, Old Dominion University.

Resnick, L. B. (2010). Nested learning systems for the thinking curriculum. Educational Researcher, 39, 183-197. http://dx.doi.org/10.3102/0013189x10364671

Rosenblatt, L. (1985). Viewpoints: transaction versus interaction-a terminological rescue operation. Research in the Teaching of English, 19, 96-107.

Ruddell, R. B., Ruddell, M. R., \& Singer, H. (1994). Theoretical models and processes of reading (4th ed.). Newark, DE, US: International Reading Association.

Rumelhart, D. E. (1980). Schemata: the building blocks of cognition. In R. J. Spiro, B. C. Bruce, \& W. F. Brewer (Eds.), Theoretical Issues in Reading Comprehension. Hillsdale, New Jersey: Lawrence Erlbaum Associations.

Rumelhart, D. E. (1985). Toward an interactive model of reading. Newark, DE: International Reading Association.

Russ-Eft, D., \& Preskill, H. (2009). Evaluation in organizations: A systematic approach to enhancing learning, performance, and change (2nd ed.). New York, NY: Basic Books.

Salmeron, L., Canas, J. J., Kintsch, W., \& Fajardo, I. (2004). Reading strategies and hypertext comprehension: Research department in experimental psychology. Spain: University of Granada.

Salton, G. (1989). Automatic text processing: the transformation, analysis, and retrieval of information by computer. Boston, MA: Addison-Wesley Longman Publishing Co., Inc.

Samuels, J. (1994). Toward a theory of automatic information processing in reading, revisited. In R. Ruddell, M. Ruddell, \& H. Singer (Eds.), Theoretical models and processes of reading (4th ed., pp. 816-837). Newark, DE: International Reading Association.

Schmitt, A. J., Hale, A. D., McCallum, E., \& Mauck, B. (2011). Accommodating remedial readers in the general education setting: Is listening-while-reading sufficient to improve factual and inferential comprehension? Psychology in the Schools, 48(1), 37-45. http://dx.doi.org/10.1002/pits.20540

Schunk, D. (2011). Learning theories: An education perspective (6th ed.). Upper Saddle River, NJ: Prentice Hall.

Schuster, J. (2012). Measuring the reading ability of incoming freshmen: A path analysis investigation into reading comprehension. ProQuest LLC, Ph.D. Dissertation, University of Kansas.

Schwartz, S. (1984). Measuring reading competence: A theoretical perspective approach. New York: Plenun Press. http://dx.doi.org/10.1007/978-1-4899-0387-7

Shang, H. (2015). An Investigation of scaffolded reading on EFL hypertext comprehension. Australasian Journal of Educational Technology, 31(3), 293-312. http://dx.doi.org/10.14742/ajet.1735

Shih, Y. (2015). The impact of extensive reading on college business majors in Taiwan. Reading Matrix: An International Online Journal, 15(1), 220-233.

Smith, F. (1982). Understanding reading: A psycho linguistic analysis of reading and learning to read (3rd ed.). New York: Holt, Rinehart \& Winston.

Snow, C., \& O'Connor, C. (2016). Close Reading and Far-Reaching Classroom Discussion: Fostering a Vital Connection. Journal of Education, 196 (1), 1-8.

Springer, S. E.; Wilson, T. J., \& Dole, J. A. (2015). Ready or not: recognizing and preparing college-ready students. Journal of Adolescent \& Adult Literacy, 58(4), 299-307. http://dx.doi.org/10.1002/jaal.363

Stanovich, K. E. (1980). Towards an interactive compensatory model of individual differences in the development of reading fluency. Reading Research Quarterly 16(1), 32-71. http://dx.doi.org/10.2307/747348

Stubbs, M. (2001). Words and phrases: Corpus studies of lexical semantics. Massachusetts: Blackwell Publishers Inc.

Tang, L. (2016). Exploration on cultivation of critical thinking in college intensive reading course. English Language Teaching, 9(3), 18-23. http://dx.doi.org/10.5539/elt.v9n3p18

The University of Kansas. (2015). Cognitive strategies. Retrieved from http://www.specialconnections.ku.edu/?q=instruction/cognitive.

Thomas, A. K., \& McDaniel, M. (2007). Metacomprehension for educationally relevant materials: Dramatic 
effects of encoding-retrieval interactions. Psychonomic Bulletin \& Review, 14(2), 212-218. http://dx.doi.org/10.3758/bf03194054

Tsai, Y., Ouyang, C., \& Chang, Y. (2016). Identifying engineering students' English sentence reading comprehension Errors: applying a data mining technique. Journal of Educational Computing Research, 54(1), 62-84. http://dx.doi.org/10.1177/0735633115605591

Wilson, B. G. (2005). Broadening our foundation for instructional design: Four pillars of practice. Educational Technology, 45(2), 10-16.

Wilson-Fowler, E. B., \& Apel, K. (2015). Influence of morphological awareness on college students' literacy skills: A path analytic approach. Journal of Literacy Research, 47(3), 405-432. http://dx.doi.org/10.1177/1086296x15619730

Wright, S., Fugett, A., \& Caputa, F. (2013). Using e-readers and internet resources to support comprehension. Educational Technology \& Society, 16(1), 367-379.

Yang, L., \& Han, G. (2009). Critical thinking and autonomy in foreign language learning. Northeast Agriculture University Journal, 7(3), 95-97.

Yang, Y. F. (2010). Developing a reciprocal teaching/learning system for college remedial reading instruction. Computers \& Education, 55, 1193-1201. http://dx.doi.org/10.1016/j.compedu.2010.05.016

Zhang, D. (2010). Study on the teaching model based on multimedia and network environment. International Education Studies, 3(1), 161-164. http://dx.doi.org/10.5539/ies.v3n1p161.

Zhang, X. (2009). An Interface between critical thinking and reading-to-writing instruction. Beijing International Studies University Journal, 10, 73-78.

Zhong, Q. (2002). Critical thinking and its teaching. Global Education, 1, 34-38.

\section{Copyrights}

Copyright for this article is retained by the author(s), with first publication rights granted to the journal.

This is an open-access article distributed under the terms and conditions of the Creative Commons Attribution license (http://creativecommons.org/licenses/by/3.0/). 